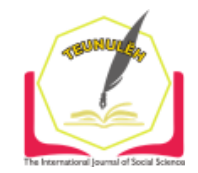

Jurnal Ilmiah Teunuleh

The International Journal of Social Sciences

Vol. 1, Issue. 2, Dec 2020

E-ISSN: 2746-4393

\title{
THE EFFECT OF PICTURE AND PICTURE LEARNING MODELS ON ELEMENTARY SCHOOL STUDENT LEARNING OUTCOMES
}

\author{
Zulfadli $^{1}$ \\ Mardhatillah' \\ Inayatun Husna ${ }^{3}$ \\ Agus Kistian ${ }^{4}$ \\ ${ }^{1}$ Studied Master Degree of Business Administration (MBA) at Murray State University \\ ${ }^{234}$ STKIP Bina Bangsa Meulaboh, Jl. Nasional Meulaboh-Tapaktuan Peunaga Cut Ujong Kec. \\ Meureubo Kab. Aceh Barat 23615
}

\begin{abstract}
This study aims to find out the influence of picture and picture learning models on the learning outcomes of grade II students at SD Negeri 1 Simpang 4 on the theme of clean and healthy living. The approach used in this research is a quantitative approach with the type of research used is quasi experimentation. The sample in this study consisted of 42 people consisting of 21 people of class IIA and 21 people of class IIB. Data collection techniques used are observation, test, validation, and documentation. The data analysis technique used is the T-test analysis. Based on the results of the study, it was found that the average posttest value of students' learning outcomes in the experimental class (II-B) of SD Negeri I Simpang Peut Nagan Raya regency was 76.19, while the average posttest score of students in the control class (II-B) of SD Negeri I Simpang Peut Nagan Raya regency was 63.33. This is proven by the results of statistical data analysis "T-Test Test" that obtained thitung value $(3,339)>t_{\text {tabel }}(1,724)$. This proves that hypotheses are accepted. Thus, it can be concluded that the picture and picture learning model affects students' learning outcomes on the theme of clean and healthy living in grade II of SD Negeri 1 Simpang Peut.
\end{abstract}

Keywords: Influence, Picture and Picture, students learning outcomes, clean and healthy living.

\section{A. Introduction}

Education is one of the most important aspects of life in the effort to build and form quality human beings. To realize quality human resources and be able to be 
effective for the development of the nation, there needs to be support from education to make it happen. According to Law No. 20 of 2003, "Education is a conscious and planned effort to realize the atmosphere of learning and learning process so that learners actively develop their potential to have religious spiritual power, self-control, personality, intelligence, noble character, and the necessary skills of themselves, society, nation, and state" (Fatimah \& Soewarno, 2016, p. 20)

Education is an obligation for every society both young and old, the goal is to achieve and make a civil society, namely civil tapestry in a spritual, economic, social, political and cultural. (Khausar, 2017, p. 42)

Improving the quality of education is directed to improve the quality of Indonesian people completely through the inner process (aspects of transdensi), thought (cognitive aspects), taste (affection aspects), and performance (psychomotor aspects) in order to have competitiveness in facing global challenges, (Trianto, 2014, p. 3). Education is very related to learning, the success of the learning process is inseparable from the ability of teachers.

In the whole process of education in schools, learning activities are the most important activities. This means that whether or not successful attainment of educational goals depends largely on how the learning process is experienced by students as students. One indicator of the success of the teaching and learning process is the learning outcomes achieved by students (Kistian, 2018, p. 14)

Elementary teachers are the spearhead in primary education. Therefore, elementary school teachers must master various teacher competencies, one of the competencies that must be mastered is professional competency. Professional teachers are able to use learning models that are oriented towards increasing the intensity of student involvement effectively in the learning process. The use of the right learning model aims to enable students to learn actively and enjoyablely so that students can achieve optimal learning outcomes (Prihatiningsih \& Setyanigtyas, 2018, p. 3).

Teaching and learning activities are a process of interaction between teachers and students in transferring knowledge, values and attitudes in educational activities in the classroom. In other words, the teacher teaches so that the learner can learn and master the content of the lesson so that it achieves something objective that is determined, can also influence the change of attitude, as well as the skills of a learner. Teaching and learning must be carried out optimally so that the learning objectives are optimal, (Husain, 2016, p. 46). 
The Effect of Picture and Picture Learning Models...

The teacher's function in planning and implementing the learning process is a major factor in achieving the learning objectives. The skills of planning and implementing this learning process are closely related to the duties and responsibilities of teachers as educational teachers. Teachers as educators have a very broad meaning, not limited to providing teaching materials, but reaching out to ethical and aesthetic behaviors in the face of life's challenges in society. (Hasyim, 2014, p. 266)

Learning models are needed in schools, especially for classroom learning. A learning model is a plan or pattern used as a guideline in planning classroom learning or tutorial learning. The model used by teachers in teaching is expected to be more effective in achieving learning objectives. (Nasution, 2017, p. 9)

Among the many learning models one of the models that has advantages is good enough for the implementation of learning in thematic subjects that provide opportunities for students to think more actively and cooperate by using images as a medium is the picture and picture model. Because, judging from the exaggerated picture and picture model according to Istarani (Istarani, 2011, p. 8) is the material taught more directed because at the beginning of the lesson the teacher explains the competencies that must be achieved and the material briefly first, students are quicker to capture the teaching material because the teacher shows pictures of the material studied, can increase the reasoning or thinking power of the student because the student is told by the teacher to analyze the existing image.

Picture and picture learning model is one of the cooperative learning models. Picture and picture learning model is a learning method that uses images and is paired or sorted into logical order. This learning has the characteristics of Active, Innovative, Creative, and Fun. Picture and picture learning model, relyingon images as a medium in the learning process. These images become a major factor in the learning process. (Fansury \& Januarty, 2017, p. 75)

Related to the above, students are expected to be eager to learn and achieve satisfactory learning outcomes by using picture and picture models, so that learning results can be achieved optimally. Based on the observations on the date up to 2019 conducted by researchers at SD Negeri I Simpang 4, it is obtained that the learning process carried out by teachers is still carried out in a conventional and monotonous way, so that the teaching and learning activities that have been carried out still seem boring and also still have not fully implemented cooperative learning models in applying learning materials in class so that students have difficulty understanding the materials 
delivered by teachers. Researchers conducted research on 2 classes, namely: experimental classes were given the treatment of picture and picture learning models and control classes given conventional learning treatment. According to Wina Sanjaya (Sanjaya, 2011, p. 270) conventional learning models of learning are entirely at the control of teachers, students exploring and listening.

Learning is still teacher centered which makes students only as listeners who follow the commands of what the teacher wants so that the impact makes the students inactive. Based on the learning outcomes of grade 2 students at SD Negeri 1 Simpang 4 obtained the completedness of low student learning outcomes, the grade 2 midterm test in grade 2 thematic subjects is known that as many as 20 students (57\%) the average value is still below the KKM standard (minimum completedness criteria) i.e. <70. Meanwhile, students who get an average score above KKM (minimum completedness criteria) of $\geq 70$ are as many as 10 students (20\%). Thus, it can be concluded that most of the students in grade 2 of SD Negeri 1 Simpang 4 as many as 35 students from the number of students, the learning results are still low or the average score is still below the kkm standard (minimum completedness criteria) namely $<70$.

Picture and Picture learning models give students the opportunity to think more actively and work together. Related to this, students are expected to be enthusiastic and interested in learning and achieving satisfactory learning outcomes by using picture and picture learning models so that the learning results can be optimal. Problems experienced by students have an impact on learning outcomes that are not maximal. This situation is not entirely the student's fault, but all aspects of education must be improved so that student learning outcomes can improve. Based on the description above, the research aims to examine the learning outcomes and learning interests of students using appropriate learning models.

\section{B. METHOD}

The approach used in this research is quantitative approach, which is an approach that allows the recording and analysis of research data in an excretion and analyzing data using statistical calculations.

This type of research uses kuasi experiments. Experiments are called kuasi, because they are not pure experiments but pure, as if they were pure. This experiment is also called pseudo-experiment. Due to various things, especially with regard to variable control, it is very difficult to use pure experimentation (Nana, 2010, p. 207). Kuasi 
The Effect of Picture and Picture Learning Models...

experiment is a type of research that compares the influenceof treatmenton an object (experimental group) and sees the influence of treatment

Samples are part or representative of the population studied. (Taniredja \& Mustafidah, 2014, p. 34). Samples in this study consisting of grade II-A as many as 21 students as a control class and II-B as many as 21 students as experimental classes.

To obtain data in this research, data collection techniques are carried out, among others:

1. Observation

Observasi is a way to conduct assessments by conducting observations directly and systematically. (Taniredja \& Mustafidah, 2014, p. 47)

2. Test

Test is a way (which can be used) or procedure (which needs to be taken) in the framework of measurement and assessment in the field of education, in the form of assignments or a series of tasks either in the form of questions (which must be answered) or commands (which must be done) by the testee. (Taniredja \& Mustafidah, 2014, p. 49)

3. Validation

Validation is a measure that indicates the degree of validity or validity of an instrument. (Arikunto, 2010, p. 211)

4. Documentation

Documentation of the origin of the word document, which means written items. In carrying out the documentation method, researchers examined written objects such as books, magazines, documents, rules, minutes of meetings, diaries and so on. (Arikunto, 2010, p. 201)

Data analysis techniques are performed using statistical tests on pretest data results, posttest from experimental classes and control classes. To test the hypothesis, statistical analysis of two average similarities between the experimental group and the control group after previously conducted data normality and homogeneity testing.

Hypothesis test is done using T-test analysis analyzed through SPSS application. 20. The level of sigfinakannya is $5 \%$. The purpose of the T-test of two free variables is to compare (distinguish) whether the two variables are the same or different. The formula of t-test is two variables as follows: (Riduwan, 2014, p. 164).

The hypothesis in this study is:

$\mathrm{H}_{\mathrm{o}}=$ There is no influence of the model pelearning picture and picture on the learning outcomes of grade II students at SD Negeri 1 Simpang Peut. 
$\mathrm{H}_{\mathrm{a}}=$ There is an influence of the model pelearning picture and picture on the learning outcomes of grade II students at SD Negeri 1 Simpang Peut.

\section{Research and Discussion Results}

\section{Test Results of Experiments and Controls on Pretest}

Comparison of dor initial test score results of students in experimental class and ontrol classcanbe presented in the table below:

Table 1: Comparison of Pretest Value Results

\begin{tabular}{lrr}
\hline Classification & Experiment Pretes & Pretest Control \\
\hline N & 21 & 21 \\
Mean & 56,19 & 55,71 \\
Median & 60,00 & 60,00 \\
Std. Deviation & 13,593 & 14,687 \\
Minimum & 30 & 30 \\
Maximum & 80 & 80 \\
Sum & 1180 & 1170 \\
\hline Source: 2019 Research Results Data & &
\end{tabular}

Based on the table of control class pretest results with the above experiment class, the results are slightly different where the student's learning results are obtained before the treatment of picture and picture learning model of the classroom learning atmosphere that has not been well organized to follow the learning. Learning is still centered on teachers as the only learning resource for them, so the opportunity for students to participate in learning becomes very small. In addition, communication between students and teachers has not been communicative and conducive, because students are still afraid to ask questions, embarrassed and have low confidence. Interaction between students is also felt to be individual, so that students who have good learning outcomes will continue to advance, while for students who have low learning outcomes are getting worse in learning activities.

\section{Test Results of Experiments and Controls on Post-test}

The post-test assessment in the control class and the experiment class aims to determine the student's final grades after the use of the learning model. In the control class, conventional learning models were carried out while in the experimental class, picture and picture learning models were carried out. Based on the results of research 
The Effect of Picture and Picture Learning Models...

data calculation on postest results can be seen in the following postest value comparison table:

The post-test assessment in the control class and the experiment class aims to determine the student's final grades after the use of the learning model. In the control class, conventional learning models are carried out while in the experimental class, picture and picture learning models are carried out. Based on the results of research data calculation on postest results can be seen in the following postest value comparison table:

Table 2: Comparison of Postest Results

\begin{tabular}{lll}
\hline \multicolumn{1}{c}{ Classification } & $\begin{array}{c}\text { Experiment } \\
\text { Pretes }\end{array}$ & Pretest Control \\
\hline $\mathrm{N}$ & 21 & 21 \\
Mean & 76,19 & 63,33 \\
Median & 80,00 & 60,00 \\
Std. Deviation & 11,170 & 13,166 \\
Minimum & 50 & 40 \\
Maximum & 100 & 90 \\
Sum & 1600 & 1330 \\
\hline
\end{tabular}

Source: 2019 Research Results Data

Based on the table above, of the 21 students sampled obtained the lowest score in the control class was 40 and the highest score was 90. The average score is 63.33, standart deviation is 13.166, and the median (middle value) is 60 , while the number of scores obtained is 1330 .

The results of the calculation of research data on postest results in the experimental class can be found that the lowest value is 50 and the highest value is 100. Average value is 76.19 , standart deviation is 11,170 . The median (middle value) is 80 , while the number of scores obtained is 1600 .

\section{Hypothesis Test}

Based on normality results to postest value data it is known that the postest grades of experimental class students as well as control classes on the theme of clean and healthy living are distributed normally. The $p$ grade for the experiment class is 0.137 and the $p$ for the control class is 0.266 . Data is normally distributed if the value is $p>0.05$. The 
second $p$ grade of a large sample class of 0.05 can be interpreted as normal distributed control class and experiment class data.

Homogeneity calculation using Annova test is done with the help of SPSS 20 software. Based on the calculation, obtained $p$ value of 0.585 . The condition of the data is said to be homogeneous if the value of calculated significance is greater than 0.05 . The $p$ value obtained is $0.585(0.855>0.05)$ so it can be concluded that the data in the control and experiment classes are homogeneous.

Skor average posttest obtained by the experimental group was 76.19 and the control group was 63.33. The results of different test calculations mean the results of learning using t-test obtained the price of $t$ calculate $(3,339)>t$ table $(1724)$ and the significance value is less than $0.05(p=3,339>1,724)$. If $t_{\text {count }}>t_{\text {table }}$ significance level of $5 \%$ with $d f=20$, then ha accepted, andvice versa if $t_{\text {count }}<t_{\text {table }}$ then a rejected and ho accepted. So it can be concluded that Ha which reads "There is an influence of picture and picture learning models on student learning outcomes in grade II of SD Negeri Simpang Peut on the theme of clean and healthy living", was accepted.

\section{Observation Results}

a. The percentage value obtained by teachers in the implementation of this picture and picture learning model is $80 \%$. So that for a while it can be concluded that the activities of teachers in the application of picture and picture learning models are included in the good category.

b. Student activities in carrying out the learning process on the theme of clean and healthy living through the application of picture and picture learning models are included in the good category.

\section{Discussion}

The results of the research on the influence of picture and picture learning models on the learning outcomes of grade II students at SD Negeri I Simpang Peut Nagan Raya district were obtained by comparing the average score of the initial test and the final test score of grade II-B students (experimental class), the data of teaching results in the initial test and the final test are presented in the following figure: 
The Effect of Picture and Picture Learning Models...

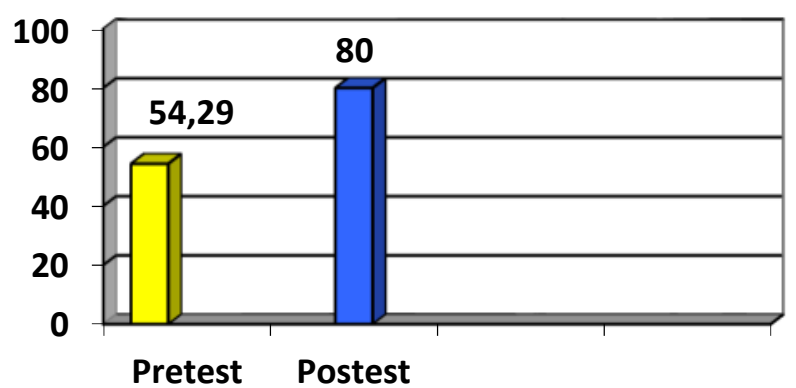

Figure 1: Differences in Pretest and Postest Learning Outcomes in Experimental Classes

Based on Figure above, in the initial test students who studied using conventional learning models obtained an average score of 54.29, while the average final test score of students who studied using a picture and picture learning model obtained an average score of 80 .

Students' learning outcomes on the theme of clean and healthy living in grade II were shown by a post-test $T$ test which was known to average student learning outcomes in the ekeperiment class of 76.19 and the average learning outcome of control class students was 63.33, so it can be concluded that the average difference in student learning outcomes in the experiment class and control class was 12.86 . From the table is known $t_{\text {count }}$ of 3.339. Obtained $t_{\text {table }}$ from df 20 at the level of significance $5 \%$ is 1,724 . So the $t_{\text {count }}>t_{\text {table }}(3.339>1.724)$ can be concluded that there is a significant difference in the value of students' learning outcomes in the experimental class.

According to Sanjaya in Tati \& Bermawi (2014), stated that conventional learning (using lectures only) is less effective against student learning outcomes. This is because in the process, the learning that takes place is only centered on the teacher (teacher centered) so that it will be difficult to develop students' ability in negotiating ability, relationships in terms of socialization ability, interpersonal relationships of students that will have an impact on the student's own learning outcomes.

Picture and picture learning models implemented in experimental classes make students more active and enthusiastic in the learning process. There is a lot of interaction between students and other learners. The atmosphere that occurs in the learning process becomes more enjoyable, the learners are not easily bored, the learners become more easily accepted the lessons given so as to improve the learning outcomes of the learners. 


\section{Conclusions}

Based on the analysis and discussion that has been done in the previous chapter, it can be concluded that the picture and picture learning model affects students' learning outcomes on the theme of clean and healthy living in grade II SD Negeri 1 Simpang Peut. This can be seen from the average posttest value of students' learning outcomes in the experimental class (II-B) of SD Negeri I Simpang Peut Nagan Raya Regency is 76.19, while the average posttest score of students in the control class (II-B) of SD Negeri I Simpang Peut Nagan Raya is 63.33.

Based on these differences indicated that students' learning outcomes at the posttest grades between the experimental class and the control class had significant differences. This is proven by the analysis of statistical data "T-Test Test" that obtained the value of $t_{\text {count }}(3.339)>t_{\text {table }}$ (1.724). This proves that hypotheses are accepted.

\section{Advice}

Based on the conclusion of the research results, the authors provide some suggestions with the aim of contributing thought to improve:

1. As an alternative for teachers in carrying out the learning process in the classroom by using picture and picture learning models, so that the learning process becomes fun and not monotonous.

2. In the process of picture and picture learning model the role of teachers is very important in controlling the students' practice. Because what if the student is not monitored properly can disturb the other students.

3. In the learning process, students should be more active in finding information to find knowledge information, so that during the learning process students get new experiences and knowledge gained themselves more easily remembered.

4. In order to improve the quality and quality of education in schools, each teacher in the field of study should prepare the maximum way of teaching by determining the learning model that is in accordance with the characteristics of the students and the subject matter itself.

\section{Bibliography}

Arikunto, S. (2010). Prosedur Penelitian Penelitian Suatu Pendekatan Praktik. Jakarta: Rineka Cipta. 
The Effect of Picture and Picture Learning Models...

Fansury, A. H., \& Januarty, R. (2017). Model Pembelajaran Picture And Picture Dengan Media Games Android Dalam Meningkatkan Kemampuan Kosa Kata Siswa Kelas VII SMPN 35 Makassar. Jurnal Keguruan dan IImu Pendidikan, 4(1), 73-85.

Fatimah, \& Soewarno. (2016). Pengaruh Model Pembelajaran Picture Terhadap Hasil Belajar Pada Subtema Indonesiaku Bangsa Yang Berbudaya Kelas V Banda Aceh. IImiah Pendidikan Guru Sekolah Dasar, 1(2).

Hasyim, M. (2014). Penerapan Fungsi Guru Dalam Proses Pembelajaran. Jurnal Auladuna, 1(2), 265-276.

Husain, B. (2016). Penggunaan Media Audio-Visual Berbasis Kearifan Budaya Lokal Pada Pembelajaran Bahasa Inggris Untuk Menanamkan Sikap Nasionalisme. DODOTO: Jurnal Pendidikan, 12(12).

Istarani. (2011). 58 Model Pembelajaran Inovatif (Referensi Guru Dalam Menentukan Model Pembelajaran). Medan: Media Persada.

Khausar. (2017). Upaya dan peran institusi lokal (balee inong) dalam menanamkan nilainilai pendidikan Islam bagi ibu-ibu dan remaja Kota Banda Aceh. Genta Mulia: Jurnal Ilmiah Pendidikan, 8(2), 41-53.

Kistian, A. (2018). Pengaruh Model Pembelajaran Contextual Teaching And Learning (CTL) Terhadap Hasil Belajar Matematika Siswa Kelas IV SD Negeri Langung Kabupaten Aceh Barat. Jurnal Bina Gogik, 5(2), 13-24.

Nana. (2010). Metode Penelitian Pendidikan. Bandung: Remaja Rosdakarya.

Nasution, M. K. (2017). Penggunaan Metode Pembelajaran Dalam Peningkatan Hasil Belajar Siswa. Studia Didaktika: Jurnal Ilmiah Bidang Kependidikan, 11(1), 9-16.

Prihatiningsih, E., \& Setyanigtyas, E. W. (2018). Pengaruh Penerapan Model Pembelajaran Picture And Picture dan Model Make A Match Terhadap Hasil Belajar Siswa. Jurnal Pendidikan Sekolah Dasar, 4(1), 1-14.

Riduwan. (2014). Metode \& Teknik Menyusun Tesis. Bandung: Alfabeta.

Sanjaya, W. (2011). Strategi Pembelajaran Berorientasi Standar Proses Pendidikan. Jakarta: Kencana.

Taniredja, T., \& Mustafidah, H. (2014). Penelitian Kuantitatif (Sebuah Pengantar). Bandung: Alfabeta.

Trianto. (2014). Model Pembelajaran Terpadu: Konsep, Strategi, dan Implementasinya Dalam Kurikulum Tingkat Satuan Pendidikan (KTSP). Jakarta: Bumi Aksara. 